\title{
Implementasi Peraturan Pemerintah Nomor 53 Tahun 2010 tentang Disiplin Pegawai Negeri Sipil
}

\section{Implementation of Government Regulation Number 53 of 2010 concerning Discipline of Civil Servants Neny Ratika Syari' ${ }^{1)}$, Warjio' ${ }^{2)}$ \& Abdul Kadir ${ }^{3)}$}

1) Pasca Sarjana Magister Ilmu Administrasi Publik Universitas Medan Area, Indonesia

2) Departemen Ilmu Politik, Fakultas Ilmu Sosial dan Ilmu Politik,

Universitas Sumatera Utara, Indonesia

3) Program Studi Administrasi Publik, Fakultas Ilmu Sosial dan Ilmu Politik, Universitas Medan Area, Indonesia

\begin{abstract}
Abstrak
Tujuan penelitian yang hendak dicapai adalah sebagai berikut: Untuk megetahui bagaimana Implementasi, factor, upaya dan hambatan dari Peraturan Pemerintah Nomor 53 Tahun 2010 Tentang Disiplin Pegawai Negeri Sipil Di Dinas Kepemudaan, Olah Raga Dan Pariwisata Kota Tanjungbalai. Implementasi Peraturan Pemerintah Nomor 53 Tahun 2010 Tentang Disiplin Pegawai Negeri Sipil Di Dinas Kepemudaan, Olah Raga Dan Pariwisata Kota Tanjungbalai belum terlaksana dengan baik sebab masih ada sebagian Pegawai Negeri Sipil yang belum sepenuhnya sadar bahkan sering kali melanggar praturan yang ada, sekalipun, pihak dinas sudah mengadakan sosialisai tentang Peraturan Pemerintah ini, akan tetapi mereka juga mengatakan bahwa Peraturan Pemerintah ini sangat membantu dalam meningkatkan kinerja yang efektif dan efisien dari PNS yang ada di Dinas Kepemudaan, Olah Raga Dan Pariwisata Kota Tanjungbalai. Ketegasan dari Kepala Dinas belum terlalu maksimal sehingga masih ada beberapapegawai di Dinas Kepemudaan, Olah Raga Dan Pariwisata Kota Tanjungbalai yangmasih belum efisien dalam menyelesaikan tugas dan tanggung jawab yang diberikan.
\end{abstract}

Kata Kunci: Implementasi, Peraturan Pemerintah, Disiplin, Pegawai Negeri Sipil

Abstract
The research objectives to be achieved are as follows: To find out how the Implementation, factors, efforts and obstacles of Government Regulation Number 53 of 2010 Concerning Discipline of Civil Servants in the Department of Youth, Sports and Tourism of Tanjungbalai City. Implementation of Government Regulation Number 53 Year 2010 Concerning Discipline of Civil Servants in the Youth, Sports and Tourism Office of Tanjungbalai City has not been carried out properly because there are still some Civil Servants who are not fully aware of even often violating existing regulations, even though, the official has held a socialization about this Government Regulation, but they also said that this Government Regulation was very helpful in improving the effective and efficient performance of civil servants in the Department of Youth, Sports and Tourism of Tanjungbalai City. The firmness of the Head of Service is not yet maximal so that there are still several employees in the Department of Youth, Sports and Tourism of the City of Tanjungbalai who are still not efficient in completing the assigned tasks and responsibilities.

Keywords: Implementation, Government Regulations, Discipline, Civil Servants

How to Cite: Syari N.R, Warjio, Kadir A. (2020) Implementasi Peraturan Pemerintah Nomor 53 Tahun 2010 Tentang Disiplin Pegawai Negeri Sipil Di Dinas Kepemudaan, Olah Raga Dan Pariwisata Kota Tanjungbalai. Strukturasi: Jurnal Ilmiah Magister Administrasi Publik, 1(2) 2020: 156-164.

*E-mail: nenyratikasyari@gmail.com 


\section{PENDAHULUAN}

Dinas Kepemudaan, Olah Raga Dan Pariwisata Kota Tanjungbalai merupakan salah satu perangkat daerah yang memiliki tugas pokok untuk melaksanakan sebagian urusan lingkup manajemen Peraturan Pemerintah Nomor 53 Tahun 2010 Tentang Disiplin Pegawai Negeri Sipil adalah kesanggupan Pegawai Negeri Sipil untuk menaati kewajiban dan menghindari larangan yang ditentukan dalam peraturan perundang-undangan dan/atau peraturan kedinasan yang apabila tidak ditaati atau dilanggar dijatuhi hukuman disiplin. Disiplin kerja merupakan salah satu faktor yang dapat mempengaruhi kinerja pegawai (Pinayungan, et .all,2018). Kurangnya kedisiplinan dan tidak taatnya terhadap peraturan dan norma-norma yang berlaku maka akan berpengaruh terhadap efisiensi dan efektifitas kerja (Nasution \& Abdul, 2015; Sarumaha \& Rosmala, 2016; Harahap \& Nina, 2016). Bila kedisiplinan tidak ditegakkan maka kemungkinan tujuan yang telah ditetapkan tidak dapat dicapai secara efektif dan efisien. Kedisiplinan pegawai salah satu tercermin dari pegawai yang tidak dapat menyelesaikan pekerjaan sesuai dengan waktu yang ditetapkan (Marpaung, 2011; Ismail, Harahap \& Kariono, 2018; Munthe, Warjio \& Kariono, 2018). Selain itu terlihat dari pegawai yang tidak masuk kerja tanpa memberikan keterangan.

Fenomena yang terjaadi saat ini adalah kurangnya tingkat disiplin kerja di Dinas Kepemudaan, Olah Raga Dan Pariwisata Kota Tanjungbalai sejak dikeluarkannya Peraturan Pemerintah (PP) Nomor 53 Tahun 2010 tentang Disiplin Pegawai Negeri Sipil (jaffisa, et .all,2017). Peraturan Pemerintah Nomor 53 Tahun 2010 ini diberlakukan mulai bulan Juni 2010, sehingga segala hal yang berhubungan dengan Disiplin PNS mengacu pada Peraturan Pemerintah (PP) ini ada beberapa Pegawai Negeri Sipil di Dinas Kepemudaan, Olah Raga Dan Pariwisata Kota Tanjungbalai yang tidak menghiraukan Peraturan Pemerintah tersebut, bahkan peraturan yang sudah ada tidak dihiraukan sama sekali (Ngarsiningtyas \& Sembiring, 2016). Pelanggaran demi pelanggaran sudah berjalan sejak lama namun kurangnya komunikasi antara Aparatur Sipil Negara dengan Kepala Dinas sehingga perbuatan melanggar hukum kedisiplinan tetap berjalan seperti biasanya. Dilingkungan Dinas Kepemudaan, Olah Raga Dan Pariwisata Kota Tanjungbalai, telah mengimplementasikan peraturan disiplin Pegawai Negeri Sipil (PNS), tetapi tidak menutup kemungkinan untuk pegawai Aparatur Sipil Negara yang ada di Dinas Kepemudaan, Olah Raga Dan Pariwisata Kota Tanjungbalai, melakukan hal-hal yang dapat menurunkan kehormatan atau martabat Negara, pemerintah, atau pegawai Aparatur Sipil Negara itu sendiri, dalam hal ini ada Pegawai Negeri Sipil Dinas Kepemudaan, Olah Raga Dan Pariwisata Kota Tanjungbalai tidak ada dari tugas sebagai abdi Negara, datang terlambat dan pulang sebelum jam yang telah ditentukan (Sinulingga, et .all,2018).

\section{METODE PENELITIAN}

Penelitian ini dilakukan di Kantor Dinas Kepemudaan, Olah Raga Dan Pariwisata Kota Tanjung Balai yang beralamat di Jalan Jendral Sudirman, Kelurahan Indra Sakti, Kecamatan Tanjungbalai Selatan, Kota Tanjung Balai, Provinsi Sumatera Utara. Waktu 
Penelitian direncanakan mulai bulan Desember 2018 sampai dengan bulan Februari 2019.

Jenis penelitian ini bersifat deskriptif kualitatif dengan melakukan pengamatan langsung atau observasi, wawancara dan dokumentasi. Metode deskriptif adalah metode yang digunakan untuk meneliti status kelompok manusia, suatu obyek, suatu kondisi dan suatu sistem pemikiran serta peristiwa yang akan terjadi (Burgin, Burhan, 2012: 83)

Teknik Pengumpulan Data: a) Lilbrary Research (Penelitian Kepustakaan) Penelitian kepustakaan ini dalam penelitian ini adalah sebagai salah satu cara dalam proses pengumpulan data dengan membaca buku - buku dan bahan bacaan lainnya yang relevan dengan masalah yang akan di teliti. b) Field Research (Penelitian Lapangan), Dalam riset atau penelitian lapangan yang akan di lakukan dalam mencari data dan infomasi di mana penelitian di lakukan secara langsung terjun ke lapangan dengan melakukan cara sebagai berikut: 1) Observasi yaitu studi atau pengamatan tentang suatu permasalahan yang di lakukan secara langsung dan sistematis oleh peneliti. 2) Wawancara (Interview) yaitu cara yang di lakukan peneliti kepada para pejabat yang berwewenang dalam memberikan informasi dan data yang diperlukan. 3) Informan Penelitian. Informan kunci (key informan), yaitu mereka yang mengetahui dan memiliki, dimana informan kunci dalam penelitian ini ialah: Bapak Herry Gunawan, S.Sos selaku Sekretaris Dinas Kepemudaan, Olahraga dan Pariwisata Kota Tanjungbalai.

Informan utama, yaitu mereka yang terlibat secara langsung dalam interaksi sosial yang diteliti, dimana informan utama dalam penelitian ini ialah Ibu Dewi Murni, S.Ap selaku pegawai di Sub Bagian Umum Perlengkapan dan Kepegawaian Dinas Kepemudaan, Olahraga dan Pariwisata Kota Tanjungbalai.

Informan tambahan, yaitu mereka yang dapat memberikan informasi walaupun tidak langsung terlibat dalam interaksi sosial yang ditelit, dimana informan tambahan ialah Bapak Bayu Safri Arnanda, S.STP selaku Kabid Pengembangan, Penilaian, Kinerja dan Penghargaan BKD Kota Tanjungbalai

Teknik Analisis Data, Reduksi Data, Diartikan sebagai proses pemilihan, pemusatan perhatian pada penyederhanaan pengabstrakan dan transformasi data kasar yang muncul dari catatan-catatan tertulis di lapangan. Dari pengumpulan data yang ada kemudian direduksi untuk pengorganisasian data dalam memudahkan menarik kesimpulan/ verifikasi. Penyajian Data, Sebagai sekumpulan informasi yang tersusun memberi kemungkinan adanya penarikan kesimpulan dan pengambilan tindakan data disajikan secara tertulis berdasarkan kasus-kasus faktual yang saling berkaitan dan dalam penyajian data ini digunakan untuk memahami apa yang sebenarnya terjadi pada proses pengembangan sumber daya manusia pada instansi yang diteliti. Menarik Kesimpulan, Proses mencari kesimpulan arti benda-benda, mencatat keteraturan, polapola penjelasan, konfigurasi-konfigurasi yang mungkin, alur sebab akibat dan proporsi peneliti. Kesimpulan-kesimpulan juga diverifikasi selama penelitian berlangsung untuk mencari kesimpulan akhir.

Metode penelitian analisis data ini berpedoman terhadap studi atau penelitian yang telah di lakukan pada saat penelitian di lapangan. Berbagai kesimpulan dari hasil 
penelitian dan di bandingkan dengan teori yang ada, kemudian menyimpulkan penelitian yang telah dilakukan dan selanjutnya di berikan masukan-masukan.

\section{HASIL DAN PEMBAHASAN}

\section{Implementasi Peraturan Pemerintah Nomor 53 Tahun 2010 Tentang Disiplin} Pegawai Negeri Sipil Di Dinas Kepemudaan, Olah Raga Dan Pariwisata Kota Tanjungbalai.

Aspek Komunikasi, Penulis melakukan wawancara bersama Bapak Herry Gunawan, S.Sos selaku Sekretaris Dinas Kepemudaan, Olah Raga Dan Pariwisata Kota Tanjung Balai (yang mana Disposisi Kepala Dinas Kepemudaan, Olahraga dan Pariwisata diarahkan kepada Sekretaris Disporapar untuk memberikan keterangan) sebagai berikut:

Kedisiplinan diartikan bilamana pegawai selalu datang dan pulang tepat pada waktunya, mengerjakan semua pekerjaannya dengan baik, mematuhi semua peraturan yang berlaku dan dalam kedisiplinan pegawai diperlukan peraturan dan hukuman. Peraturan itu sangat diperlukan untuk memberikan bimbingan dan penyuluhan bagi pegawai, dalam menciptakan tata tertib yang baik. Hal ini akan mendukung tercapainya tujuan di Dinas Kepemudaan, Olah Raga Dan Pariwisata Kota Tanjungbalai, dan pegawai. Dinas Kepemudaan, Olah Raga Dan Pariwisata Kota Tanjungbalai sulit mencapai tujuannya, jika pegawai tidak mematuhi peraturan-peraturan Dinas Kepemudaan, Olah Raga Dan Pariwisata Kota Tanjungbalai sesuai PP No 53 Tahun 2010 tentang Kedisplinan maka akan dikenakan sanksi hukuman kepegawaian yang berlaku. Kedisiplinan Dinas Kepemudaan, Olah Raga Dan Pariwisata Kota Tanjungbalai dikatakan masih kurang baik, jika sebagian besar pegawai mematuhi peraturan-peraturan yang ada.

Aspek Sumberdaya, Disiplin juga merupakan salah satu fungsi manajemen sumber daya manusia yang penting dan merupakan kunci terwujudnya tujuan, karena tanpa adanya disiplin maka sulit mewujudkan tujuan yang maksimal" (Sedarmayanti, 2009: 15). Melalui disiplin pula timbul keinginan dan kesadaran untuk menaati peraturan organisasi dan norma sosial. Namun tetap pengawasan terhadap pelaksanaan disiplin tersebut perlu dilakukan.

Dari penjelasan tentang disiplin dapat dipahami bahwa pada dasarnya kinerja tersebut adalah pencapaian tujuan secara berdaya guna yang juga dapat dikatakan sebagai usaha-usaha yang telah dilakukan oleh perusahaaan baik dari segi biaya, tenaga, waktu sehingga dapat mencapai tujuan yang telah ditentukan sebelumnya dengan nilai yang memuaskan. Pencapaian tujuan tersebut sangat berkaitan dengan penerapan disiplin Pegawai Negeri Sipil.

Berdasarkan wawancara dengan Sub Bagian Umum Perlengkapan dan Kepegawaian maka penulis menyimpulkan bahwa yang mendasari kenapa Pegawai Negeri Sipil tidak melaksanakan Peraturan Pemerintah ini karena karakter dari Pegawai Negeri Sipil itu sendiri, disebabkan karena kurangnya pola pikir dari Pegawai Negeri Sipil itu sendiri, untuk menaati peraturan ini. Sehingga berdampak pada kinerja Aparatur Sipil Negara dalam meningkatkan kinerja pegawai yang ada di Dinas Kepemudaan, Olah Raga Dan Pariwisata Kota Tanjungbalai. 
Aspek disposisi, Disiplin kerja adalah suatu alat yang digunakan para manajer untuk berkomunikasi dengan pegawai agar mereka bersedia untuk mengubah suatu perilaku serta sebagai suatu upaya untuk meningkatkan kesadaran dan kesediaan seseorang mentaati semua peraturan Dinas Kepemudaan, Olah Raga Dan Pariwisata Kota Tanjungbalai dan norma-norma sosial yang berlaku" (Rivai, 2014). Kedisiplinan diartikan bilamana pegawai selalu datang dan pulang tepat pada waktunya, mengerjakan semua pekerjaannya dengan baik, mematuhi semua peraturan yang berlaku dan dalam kedisiplinan pegawai diperlukan peraturan dan hukuman.

Peraturan itu sangat diperlukan untuk memberikan bimbingan dan penyuluhan bagi pegawai, dalam menciptakan tata tertib yang baik. Hal ini akan mendukung tercapainya tujuan Dinas Kepemudaan, Olah Raga Dan Pariwisata Kota Tanjungbalai, dan pegawai. Lembaga pemerintah sulit mencapai tujuannya, jika pegawai tidak mematuhi peraturan-peraturan Dinas Kepemudaan, Olah Raga Dan Pariwisata Kota Tanjungbalai tersebut. Kedisiplinan suatu lembaga pemerintah dikatakan kurang baik, jika sebagian besar pegawai mematuhi peraturan-peraturan yang ada.

Aspek Struktur Birokrasi, Berikut alur struktur birokrasi bagi Pegawai Negeri Sipil melakukan pelanggaran-pelanggaran kedisplinan, bahwa Pegawai Negeri Sipil yang ada pada Dinas Kepemudaan, Olah Raga Dan Pariwisata Kota Tanjungbalai adalah merupakan Pegawai Negeri Sipil Kabupaten/Kota. Berdasarkan data yang ditemukan, penulis memberikan penjelasan bahwa struktur sederhana paling banyak dipraktikkan dalam instansi pemerintahan maupun swasta dimana bawahan dan atasan adalah orang yang satu dan sama. Kekuatan dari struktur ini adalah kesederhanaannya yang tercermin dalam kecepatan, kefleksibelan, ketidakmahalan dalam pengelolaan, dan kejelasan akuntabilitas. Satu kelemahan utamanya adalah struktur ini sulit untuk dijalankan dimana pun selain di organisasi kecil karena struktur sederhana menjadi tidak memadai tatkala sebuah organisasi berkembang karena formalisasinya yang rendah dan sentralisasinya yang tinggi cenderung menciptakan kelebihan beban (overload) di puncak.

Sebuah struktur dengan tugas-tugas operasi yang sangat rutin yang dicapai melalui spesialisasi, aturan dan ketentuan yang sangat formal, tugas-tugas yang dikelompokkan ke dalam berbagai departemen fungsional, wewenang terpusat, rentang kendali yang sempit, dan pengambilan keputusan yang mengikuti rantai komando. Kekuatan utama birokrasi ada kemampuannya menjalankan kegiatan-kegiatan yang terstandar secara sangat efisien, sedangkan kelemahannya adalah dengan spesialisasi yang diciptakan bisa menimbulkan konflik-konflik subunit, karena tujuan-tujuan unit fungsional dapat mengalahkan tujuan keseluruhan organisasi. Kelemahan besar lainnnya adalah ketika ada kasus yang tidak sesuai sedikit saja dengan aturan, tidak ada ruang untuk modifikasi karena birokrasi hanya efisien sepanjang pegawai menghadapi masalah yang sebelumnya telah mereka hadapi dan sudah ada aturan keputusan terprogram yang mapan.

Sasaran kerja pegawai merupakan rencana kerja dan target yang akan dicapai oleh seorang pegawai yang disusun dan disepakati bersama antara pegawai dengan atasan pegawai. Sasaran kerja disini mengenai rencana dan target kerja yang harus dicapai oleh 
pegawai dalam kurun waktu yang telah ditetapkan. Pencapaian sasaran kerja ini berhubungan dengan pelaksanaan tugas oleh para pegawai, dan ketepatan waktu dalam menyelesaikan pekerjaan. Sasaran kerja pegawai bertujuan untuk mengevaluasi kinerja Pegawai Negeri Sipil dan menjamin objektivitas dalam mempertimbangkan pengangkatan dalam jabatan dan kenaikan pangkat.

Pegawai telah mengetahui rencana kerja dan target kerja yang ditetapkan bersama atasan yang sesuai dengan tugas dan fungsinya masing-masing. Berdasarkan wawancara tersebut, secara umum penetapan rencana kerja di Dinas Kepemudaan, Olah Raga Dan Pariwisata Kota Tanjungbalai dilakukan secara kelompok, yang mana dalam kelompok kerja tersebut tidak menguraikan secara rinci tugas dari masing-masing pegawai atau anggota dari setiap kelompok kerja. Namun dengan begitu, berdasarkan penilaian para atasan dari masing-masing bagian, beberapa pegawainya telah mencapai sasaran kerja yang ditetapkan dan telah menyelesaikan tugasnya tepat waktu serta menunjukkan kinerja yang cukup baik. Namun demikian, penyelesaian akhir dari belum optimalnya kinerja ASN tersebut ialah dilakukan mutasi oleh yang berwenang.

\section{Faktor-faktor Upaya dan Hambatan dalam menjalankan Implementasi Peraturan Pemerintah Nomor 53 Tahun 2010 Tentang Disiplin Pegawai Negeri Sipil di Dinas Kepemudaan, Olah Raga Dan Pariwisata Kota Tanjungbalai.}

Pemberian Sanksi, Pemberian sanksi kepada Pegawai Negeri Sipil yang melanggar peraturan pemerintah ini, sesuai hasil wawancara dengan Sekretaris Dinas Kepemudaan, Olah Raga Dan Pariwisata Kota Tanjungbalai mengatakan, sudah ada 2 orang telah dikenakan teguran lisan dan teguran tertulis yang berdampak pada penundaan gaji berkala, selain itu juga telah dikenakan penundaan kenaikan pangkat. Ini dilakukan agar penataan manajemen kepegawaian yang professional dalam rangka meningkatkan kinerja pegawai bisa dicapai dan berdasarkan hasil wawancara pemberian sanksi ini sudah sesuai dengan prosedur dalam peraturan pemerintah Nomor 53 tahun 2010 tentang Disiplin Pegawai Negeri Sipil.

Meningkatkan Disiplin Pegawai dengan Finger Print, Kedisiplinan aparatur pegawai sebagai penyelenggara pemerintahan, tentunya sangat mempengaruhi kualitas kinerja suatu pemerintahan, bahkan kedisiplinan ini bisa dikatakan sebgai salah satu indikator penting dalam mengukur keberhasilan penyelenggaraan pemerintah daerah. Tentu dalam hal ini sama juga terjadi di Dinas Kepemudaan, Olah Raga Dan Pariwisata Kota Tanjungbalai, yang mengingikan budaya kerja. Harus disadari bahwa jika ingin menegakan disiplin maka harus dimulai dari diri sendiri.Selain itu yang harus diperhitungkan adalah bahwa dari dalam dulu yang memulai menegakan kedisiplinan pasti akan banyak ditemukan tantangan-tantangan dari mereka yang sepaham akan pentingnya disiplin untuk ditegakkan karena penegakan disiplin akan memberikan implikasi bagi sebuah sikap hidup.

Pelaksanaan Reward and Punishment, Untuk Peningkatan Kinerja Pegawai Dinas Kepemudaan, Olah Raga Dan Pariwisata Kota Tanjungbalai selalu membutuhkan pelayanan publik. Pelayanan publik merupakan keharusanbagi Negara atau pemerintahan untuk melayani warga negaranya. Pelayanan publik tidak dengan mudah dapat dilakukan, bahkan banyak Negara yang gagal melakukan pelayanan publik yang baik bagi warganya. Kegagalan dan keberhasilan suatu pelayanan publik dapat ditentukan olehsuatu pelayanan public tersebut. 
Persiapan yang matang untuk merubah paradigma pelayanan akan diikuti oleh pelaksanaan yang baik. Dari pelaksanaan yang baik akanmendapatkan hasil yang baik apabila dikuti oleh konsistensi kinerja suatu teamwork. Penulis berpendapat, Kinerja pegawai di Dinas Kepemudaan, Olah Raga Dan Pariwisata Kota Tanjungbalai bisa dikategorikan cukup baik. Persiapan personil, perbaikan infrasturktur dan citra yang ditampilkan merupakan modal untuk menjadi tolak ukur pelayanan yang baik.

Pengawasan Pemerintah, Dalam penelitian ini ditemukan selain pemberian sanksi, reward, punishment maupun pengawasan adapun usaha-usaha yang dilakukan oleh Dinas Kepemudaan, Olah Raga Dan Pariwisata Kota Tanjungbalai dalam menggerakkan para pegawai agar dapat bekerjasama dalam mencapai tujuan organisasi, diantaranya adalah mengikutsertakan para pegawai dalam proses pengambilan keputusan, memecahkan dan mencari solusi atas semua persoalan yang muncul didalam kehidupan berorganisasi, menciptakan dan memelihara iklim kekeluargaan, kebersamaan, dan kerja sama dalam kehidupan berorganisasi, Memotivasi pegawai dengan memperhatikan keinginan, harapan, keperluan dan kebutuhan pegawai yang disesuaikan dengan kemampuan organisasi, dan memberikan kesempatan kepada para pegawai untuk menimba ilmu dan pengetahuan baru serta menggali keterampilan baru. Bahkan ada juga usaha-usaha yang dilakukan oleh Badan Kepegawaian Daerah Kota Tanjungbalai untuk meningkatkan kemampuan dan profesionalisme pegawainya adalah memberikan kesempatan kepada pegawai untuk mengikuti program pendidikan dan pelatihan (Diklat).

\section{Hambatan Dalam Mengimplementasikan PeraturanPemerintah Nomor 53 Tahun 2010 Tentang Disiplin Pegawai Negeri Sipil}

Setelah dilakukan wawancara kepada beberapa informan, masing-masing memberikan pendapat tentang hambatan-hambatan Pegawai Negeri Sipil dalam mengimplementasikan Peraturan Pemerintah ini. Sekretaris dan Sub Bagian Umum Perlengkapan dan Kepegawaian mengatakan, masih ada Pegawai Negeri Sipil yang kurang kesadaran dalam menjalankan Peraturan Pemerintah No 53 tahun 2010, sehingga masih terjadi pelanggaran-pelanggaran terhadap kedisiplinan pegawai. Kemudian Sub.Bag Umum. Perlengkapan dan Kepegawaian juga mengatakan, kesadaran dari Pegawai merupakan hal yang mendasari permasalahan ini. Sehingga sangat dibutuhkan ketegasan dari pemimpin untuk menindak lanjuti masalah ini, agar kinerja dari pegawai itu sendiri dapat berjalan maksimal.

Peneliti melakukan wawancara dengan Bapak Herry Gunawan, S.Sos selaku Sekretaris Dinas Kepemudaan, Olah Raga Dan Pariwisata Kota Tanjungbalai sebagai berikut: Apa yang menjadi hambatan pelaksanaan Peraturan Pemerintah No 53 tahun 2010 tentang disiplin Pegawai Negeri Sipil di Dinas Kepemudaan, Olah Raga Dan Pariwisata Kota Tanjungbalai? "Kurangnya pemberian bimbingan maupun pengarahan yang diberikan oleh berbagai pihak seperti BKD sehingga permasalahan disiplin pegawai belum dapat diselesaikan. Kurangnya dukungan pegawai dalam mentaati berbagai kesepakatan tentang peraturan disiplin pegawai dalam bekerja sehingga masih ada aturan-aturan yang telah dibuat dan disepakati bersama belum dapat terlaksana dengan baik. Kurangnya dukungan pegawai dalam mengikuti kegiatan sosialisasi tentang ketentuan-ketentuan yang telah ditetapkan sehingga masih terjadi ketidakdisiplinan pegawai dalam mematuhi berbagai ketentuan yang telah ditetapkan. Pegawai belum 
dapat melaksanakan pekerjaan yang diberikan sesuai dengan SOP karena pegawai kurang berpedoman dalam melaksanakan pekerjaan" (Sumber: Pada Tanggal 11 Februari 2019, Pukul 10.00 WIB).

\section{SIMPULAN}

Implementasi Peraturan Pemerintah Nomor 53 Tahun 2010 Tentang Disiplin Pegawai Negeri Sipil Di Dinas Kepemudaan, Olah Raga Dan Pariwisata Kota Tanjungbalai belum terlaksana dengan baik sebab masih ada beberapa Pegawai Negeri Sipil yang belum sepenuhnya sadar bahkan sering kali melanggar peraturan yang ada, sekalipun pihak dinas sudah mengadakan sosialisai tentang Peraturan Pemerintah ini, akan tetapi mereka juga mengatakan bahwa Peraturan Pemerintah ini sangat membantu dalam meningkatkan kinerja yang efektif dan efisien dari PNS yang ada di Dinas Kepemudaan, Olah Raga Dan Pariwisata Kota Tanjungbalai. Ketegasan dari Kepala Dinas belum terlalu maksimal sehingga masih ada beberapa pegawai di Dinas Kepemudaan, Olah Raga Dan Pariwisata Kota Tanjungbalai yang masih belum efisien dalam menyelesaikan tugas dan tanggung jawab yang diberikan.

Upaya dan Hambatan dalam menjalankan Implementasi Peraturan Pemerintah Nomor 53 Tahun 2010 Tentang Disiplin Pegawai Negeri Sipil Di Dinas Kepemudaan, Olah Raga Dan Pariwisata Kota Tanjungbalai bahwa pemberian sanksi kepada Pegawai Negeri Sipil, meningkatkan disiplin pegawai dengan Finger Print. pelaksanaan reward and punishment. Pengawasan yang dilakukan oleh Dinas Kepemudaan, Olah Raga Dan Pariwisata Kota Tanjungbalai sesusai dengan Tugas dan Fungsi yang dilakukan oleh Sekretaris. Akan tetapi pengawasan yang dilakukan kurang maksimal, pegawai belum dapat melaksanakan pekerjaan yang diberikan sesuai dengan SOP karena pegawai kurang berpedoman dalam melaksanakan pekerjaan.

\section{DAFTAR PUSTAKA}

Agustinus, L. (2006). Dasar-Dasar Kebijakan Publik. Bandung: Alfabeta.

Anoraga, P. (2010). Manajemen Bisnis. Jakarta: Rineka Cipta.

Davis, K. (2010). Organizational Behavior-Human Behavior at Work 13th. New Delhi: Mcgraw Hill Company. Divisi Litbang Madcoms. (2005). Seri Panduan Lengkap Myob Accounting. Yogyakarta: Andi

Eaton, D.B. (1988). Birokrasi Pemerintahan. New York: Rinehart Winston; 1977 California.

Esman, M.J. (1991). Etika Birokrasi. Jakarta: DJambatan.

Hani, T.H. (2014). Manajemen Personalia dan Sumber Daya Manusia. Yogyakarta: BPFE Yogyakarta.

Harahap, A.S., \& Nina A., Peranan Promosi Jabatan Terhadap KinerjaPegawai Negeri Sipil Di Sekretariat DPRD Kabupaten Padang Lawas, PUBLIKAUMA: Jurnal Administrasi Publik Universitas Medan Area, 4 (1): 29-42.

Hasibuan, M. (2013). Manajemen Sumber Daya Manusia. Jakarta: PT. Bumi Aksara.

Ismail, W,H, Harahap, R.H. \& Kariono. (2018). Implementasi Peraturan Menteri Agama RI Nomor 45 Tahun 2015 Tentang Disiplin Kehadiran PNS Di Lingkungan Kementerian Agama. Jurnal Administrasi Publik (Public Administration Journal). 8 (1): 124-146.

Mamesah, D.J. (2005). Sistem Administrasi Keuangan Daerah. Jakarta: Gramedia Pustaka Utama.

Mangkunegara, AA.A.P. (2014). Manajemen Sumber Daya Manusia. Bandung: PT. Remaja Rosdakarya.

Mardiasmo. (2002). Otonomi dan Manajemen Keuangan Daerah. Jakarta: Andi Publisher.

Marpaung, H.W. (2011). Implementasi Peraturan Daerah Kabupaten Labuhanbatu Nomor 37 Tahun 2008 Tentang Pembentukan Organisasi Dan Tata Kerja Kecamatan, Jurnal Administrasi Publik (Public Administration Journal), 1 (1): 29-50

Mathis, R.L. \& Jackson, J.H. (2011). Manajemen Sumber Daya Manusia. Jakarta: Pertama Salemba Empat. Moleong, L. J. (2010). Metodologi Penelitian Kualitatif. Bandung: Remaja Rosda karya. 
Munthe, S. Warjio \& Kariono. (2018). Implementasi Peraturan Pemerintah Nomor 18 Tahun 2016 tentang Perangkat Daerah pada Penataan Kelembagaan Sekretariat Daerah. JPPUMA: JPPUMA: Jurnal Ilmu Pemerintahan dan Sosial Politik UMA (Journal of Governance and Political UMA), 6 (1): 38-52.

Nasution, F.R., dan Abdul M., (2015). Evaluasi Kinerja Pegawai Dalam Pelayanan Bea Balik Nama Kendaraan Bermotor di Kantor Samsat UPT Pangkalan Brandan, PUBLIKAUMA: Jurnal Administrasi Publik Universitas Medan Area, 3 (1): 1-7

Nawawi, H. (2012). Metoda Penelitian. Yogyakarta: Gadjah mada University Press

Putera. (2000). Birokrasi Politik Di Indonesia. Jakarta: Tiara Wacana.

Sarumaha, W.Y., \& Rosmala D., (2016). Peran Camat Dalam Mengawasi Kinerja Pegawai dinKantor Camat Medan Denai Kota Medan, Jurnal Administrasi Publik Universitas Medan Area, 4 (1): $52-64$

Siswanto, B. (2010). Manajemen Tenaga Kerja Rancangan dalam Pendayagunaan dan Pengembangan Unsur Tenaga Kerja. Bandung: Sinar Baru.

Subarsono, A.G. (2011). Analisis Kebijakan Publik: Konsep, Teori Dan Aplikasi. Jakarta: Pustaka Pelajar.

Sunggono, B. (2012), Hukum dan Kebijaksanaan Publik, Penerbit: PSKK-UGM, Bandung.

Thoha, M. (2009). Kepemimpinan dalam Manajemen. Jakarta: Rajawali Press.

Wahab, A. (2005). Formulasi ke Penyusunan Model-Model Implementasi Kebijakan Publik. Jakarta: Fakultas Ekonomi Universitas Indonesia.

Wayne, M.R. (2009). Manajemen Sumber Daya Manusia. Jakarta: Erlangga.

Widodo, M.S. (2010). Konsep dan Aplikasi Analisis Proses Kebijakan Publik. Jakarta: Bayu Media.

Winarno, B. (2014). Kebijakan Publik, Teori dan Proses. Yogyakarta: Media Presindo.

Winarno, E.H. (2005). Reformasi Birokrasi, Kepemimpinan, dan Pelayanan Publik: Kajian tentang Pelaksanaan Otonomi Daerah di Indonesia. Bandung: Alfabeta.

Sinulingga, L.O. Nasution, M.H.T. \& Batubara, B.M. (2018). Implementasi Kebijakan Pajak Progresif Bagi Kendaraan Bermotor. PERSPEKTIF, 7 (1): 19-23

Pinayungan, J. Kusmanto, H. \& Isnaini. (2018). Implementasi Peraturan Menteri Perhubungan Republik Indonesia Tentang Standar Keselamatan Lalu Lintas Dan Angkutan Jalan. Jurnal Administrasi Publik :Public Administration Journal : Public Admnistration Journal. 8 (1): 108-123.

Ngarsiningtyas, S.K. \& Sembiring, W.M. (2016) Peran Badan Permusyawaratan Desa dalam Penyusunan dan Penetapan Peraturan Desa, JPPUMA: Jurnal Ilmu Pemerintahan dan Sosial Politik UMA (Journal of Governance and Political UMA), 4 (2): 159-172.

Jaffisa, T., Kadir, A. \& Dumasari, H. (2017), Peranan Camat dalam Pengawasan Disiplin Pegawai Negeri Sipil di Kantor Kecamatan, Jurnal Administrasi Publik: Public Administration Journal : Public Admnistration Journal, 7 (1): 94-93 